\title{
FAKTOR-FAKTOR YANG MEMENGARUHI KECEMASAN IBU PRE OPERASI SECTIO CAESAREA (SC) DI RUMAH SAKIT UMUM DAERAH SIDIKALANG KABUPATEN DAIRI
}

\author{
Risdiana Melinda Naibaho \\ Prodi D III Keperawatan Dairi Poltekkes Kemenkes Medan \\ risdiana.naibaho78@gmail.com
}

\begin{abstract}
Sectio caesarea is needed as an effort to deliver to save the mother and the fetus, althought at this time the trend of childbirth with sectio caesarea is increasing from year to year, however, every mother who is going to undergo labor with surgery always feels anxiety when facing sectio caesarea surgery. This type of research is a descriptive survey to describe the factor,s that influence the anxiety of pre caesarean section mothers.The population is pregnant women who will give birth by sectio caesarean surgery at the Hospital General Sidikalang Dairi Regency. Sampling with accidental sampling tehnique with a total sample of 55 preoperative caesarean section patiens was based on certain considerations made by the reseachers themselves, based on the average number of caesarean sectins in one year, as many as 1572 people, so that the average monthly number is 131 peple. The data collection tehnique was done through interviews using a questinnaire. The data obtained were analyzed by univariate, bivarriate with chi square $p$-value $95 \%(\alpha=0,05)$.The results of this study indicate that age ( $p$-value $=0,003)$, education ( -value $=0,000)$, parity $(p$-value $=0,002)$, support $(p$-value $=0,000)$, trauma $(p$-value $=0,003)$, knowledge ( $p$-value = 0,000),affect anxiety pre operative mother for section caesarea.Sugegestins for families to be given information about the secti caesarean action to be able to provide tigter support to increase confidence in preoperative mothers to increase maternal knowledge, to health workers, to be able to provide information and support to preoperative mothers to make mothers feel comfortable.
\end{abstract}

Keywords: Anxiety, Pre Sectio Caesarea

\begin{abstract}
Abstrak
Bacground :Persalian dengan sectio caesarea diperlukan sebagai upaya persalinan untuk menyelamatkan ibu dan janin, meskipun pada saat ini trend melahirkan dengan tindakan SC semakin meningkat dari tahun ke tahun walaupun demikian setiap ibu yang akan menghadapi persalinan dengan pembedahan senantiasa merasakan kecemasan ketika menghadapi tindakan operasi SC. Metode penelitian ini dengan survey deskriptif untuk menggambarkan faktor faktor yang memengaruhi kecemasan ibu pre operasi sectio caesarea Populasinya adalah ibu hamil yang akan melahirkan dengan tindakan operasi sectio caesarea di Rumah sakit Umum daerah Sidikalang Kabupaten Dairi. Pengambilan sampel dengan teknik accidental sampling dengan jumlah sampel 55 pasien pre operasi seksio sesarea didasarkan pada suatu pertimbangan tertentu yang dibuat oleh peneliti sendiri, berdasarkan rata-rata jumlah sectio caesarea dalam satu tahun, sebanyak 1572 orang. sehingga rata-rata perbulannya sebanyak 131 orang. Teknik pengumpulan data dilakukan melalui wawancara dengan menggunakan kuesioner. Data yang diperoleh dianalisis secara univariat kemudian bivariat dengan menggunakan uji Chi-square pada tingkat kepercayaan 95\% ( $\alpha=0,05)$. Hasil penelitian ini menunjukkan bahwa Umur $(p$-value $=0,003)$, Pendidikan $(p$-value $=0,000)$, Paritas $(p$-value $=0,002)$, Dukungan $(p$-value $=0,000)$ pengetahuan $(p$-value $=$ $0,000)$ artinya seluruh faktor yang diteliti memengaruhi kecemasan ibu pre operasi sectio caesarea.Saran kepada keluarga agar diberikan informasi pengetahuan tentang tindakan sectio caesarea dan dukungan secara psikososial untuk dapat memberikan dukungan yang lebih erat sehingga meningkatkan percaya diri pada ibu pre operasi. kepada tenaga kesehatan, untuk dapat memberikan informasi menyampaikan dengan komunikasi terapeutik sehingga ibu merasa nyaman dalam mempersiapkan diri untuk menjalani tindakan operasi sectio caesarea.
\end{abstract}

Kata Kunci : Kecemasan, Ibu Pre Sectio Caesarea 


\section{PENDAHULUAN}

Pre operatif dimulai ketika keputusan untuk intervensi bedah dibuat dan berakhir ketika pasien dikirim ke meja operasi (Brunner \& Suddart, 2002). Pada fase pre operatif banyak persiapan yang harus dilakukan, salah satunya adalah persiapan psikologis. Baik pasien maupun keluarga perlu diberi kesiapan untuk membicarakan isi hati dan rasa takut terhadap operasi yang akan dilakukan. Hal ini penting karena yang yang akan menjalani poperasi akan mengalami stres fisiologis maupun patologis.

Sesuai dengan perkembagan ilmu dan tehnologi bahwa tindakan operasi sectio caesarea sudah dikategorikan aman walaupun pada intinya tidak ada tindakan yang bebas dari resiko, perlu diingat bahwa tindakan operasi tentunya memiliki resiko dan efek samping baik selama proses ataupun sesudah tindakan operasi. seorang wanita yang telah menjalani operasi pasti akan memiliki cacat dan parut pada rahim yang dapat membahayakan kehamilan dan persalinan berikutnya walaupun bahaya tersebut relatif kecil. Berkat kemajuan dalam teknik operasi yang lebih sempurna antibiotik transfusi darah dan anastesi. Sehingga pada saat ini timbul kecenderungan untuk melakukan operasi tersebut tanpa dasar indikasi yang cukup kuat.

Beberapa faktor penyebab kecemasan pada ibu yang akan bersalin adalah faktor eksternal Antara lain : 1) Lingkungan baru merupakan faktor yang dapat menimbulkan stress. Pada individu yang akan menjalani operasi, kamar operasi merupakan lingkungan baru atau asing bagi individu tersebut, sehingga bila individu masuk ke kamar operasi akan mengalami cemas karena desain atau tata ruang di kamar operasi sangat berbeda dengan lingkungan di rumah. 2).Takut Dengan Operasi, Operasi merupakan sesuatu yang membuat individu menjadi cemas, jika seorang mengalami sakit divonis untuk operasi kadang mengalami cemas karena luka dan nyeri yang dialami pasien, bila seseorang membayangkan "Penyayatan Otot" dan jaringan dibawahnya oleh dokter bedah dan kemudian dijahit kembali ,takut Dengan Anastesi, Setiap individu yang akan menjalani operasi, anastesi merupakan sesuatu yang menyebabkan cemas. Karena dengan anastesi pasien berfikir akan mati, tidur terus tidak bangun.4) Kematian (death), cemas akan kematian disebabkan oleh beberapa faktor yaitu ketika pasien mengaetahui bahwa operasi yang akan dilakukan mempunyai resiko yang cukup besar pada tubuh sehingga dapt menyebabkan kematian. 5). Nyeri dan ketidaknyamanan Pada pembedahan akan timbul reaksi nyeri pada daerah luka dan pasien merasa takut untuk melakukan gerakan tubuh atau latihan ringan akibat nyeri pada daerah perlukaan yang menimbulkan cemas pada pasien pre operatif. Faktor Internal : 1).Umur menurut Kaplan dan Sadock (2007) kecemasan dapat terjadi pada semua usia, lebih sering pada usia dewasa dan lebih banyak pada wanita. Sebagian besar kecemasan terjadi pada umur 21 - 45 tahun. Manuaba (2006) juga menyebutkan bahwa usia dapat memengaruhi kecemasan pada ibu yang akan bersalin bahwa usia $<20$ tahun dan $>30$ tahun akan memberi dampak terhadap perasaan cemas semakin muda usia atau semakin tua akan beresiko terhadap proses persalinan.2) Jenis Kelamin menurut Prasetyo (2010), kecemasan dapat dialami oleh setiap individu, pasien yang akan menjalani operasi dan masuk ke kamar operasi akan mengalami cemas. Jumlah wanita yang mengalami kecemasan dua kali lipat dari pria. 3) Pendidikan seseorang akan berpengaruh terhadap kemampuan berfikir, semakin tinggi tingkat pendidikan akan semakin mudah berfikir rasional dan semakin mudah menangkap informasi baru termasuk dalam menguraikan permasalahan baru.4) Pengetahuan pasien pre operatif akan merasa cemas oleh karena ketidaktahuannya baik karena prosedur pembedahan maupun anastesi. 5) Pekerjaan, pembedahan dapat menyebabkan perubahan fisik yang membuat pasien tidak bisa kembali bekerja dan bahkan kehilangan pekerjaan karena ketidakmampuannya, maka perawat perlu mengkaji riwayat pekerjaan pasien untuk mengantisipasi efek pada masa pemulihan yang mungkin terjadi akibat pembedahan dan penampilan pasien saat bekerja kembali (Potter, 2006), 6) Paritas Manuaba (2006) menjelaskan bahwa ibu yang akan bersalin akan merasakan kecemasan terkait dengan aspek psikologis dimana belum ada gambaran bagi ibu yang pertama kali akan menjalani proses persalinan dengan pembedahan ,bisa saja disebakan karena adanya ketakutan oleh karena mendengarkan cerita pengalaman orang lain. 7) Ketidak Tahuan ( unknow) cemas pada hal-hal yang belum diketahui sebelumnya adalah suatu hal yang umum terjadi.Ini disebabkan karena kurangnya informasi tentang pembedahan.

Berdasarkan data Riset Kesehatan Dasar Nasional (RISKESDAS) pada tahun 2010 ibu melahirkan dengan operasi SC adalah 15,3\%, tertinggi berada di DKI Jakarta dengan prevelensi 27,2\% sedangkan angka terendah adalah di Sulawesi Tenggara dengan prevelensi 5,5\% dan Sumatera Utara berada pada urutan ke 7 dengan prevelensi $11,3 \%$. Walaupun secara terjadi penurunan, tetapi berdasarkan alasan terjadi trend peningkatan SC tanpa indikasi medis.

Berdasarkan survey awal yang dilakukan dengan wawancara terhadap $8 \mathrm{ibu}$ pre operasi sectio caesarea menyatakan 2 orang diantaranya megatakan cemas terhadap nyeri atau kematian karena sebelumnnya belum pernah dioperasi, 2 orang mengatakan cemas perasaan tidak menentu, 2 orang takut pada tindakan dan efek dari anastesi saat menghadapi sectio caesarea, 1 orang cemas terjadi kesalahan saat operasi, 1 orang cemas terhadap nyeri selama melakukan parsiapan operasi karena sudah pernah dioperasi sebelummnya. 


\section{METODE PENELITIAN}

Jenis penelitian ini adalah survey deskriptif untuk menggambarkan faktor faktor yang memengaruhi kecemasan ibu pre operasi sectio caesarea. Populasinya adalah ibu hamil yang akan melahirkan dengan tindakan operasi sectio caesarea di Rumah sakit Umum daerah Sidikalang Kabupaten Dairi. Pengambilan sampel dengan teknik accidental sampling dengan jumlah sampel 55 pasien pre operasi seksio sesarea didasarkan pada suatu pertimbangan tertentu yang dibuat oleh peneliti sendiri, berdasarkan rata-rata jumlah secti caesarea dalam satu tahun sebanyak 1572 orang. sehingga rata-rata perbulannya sebanyak 131 orang. Teknik pengumpulan data dilakukan melalui wawancara dengan menggunakan kuesioner. Data yang diperoleh dianalisis secara univariat kemudian bivariat dengan menggunakan uji Chi-square pada tingkat kepercayaan $95 \%(\alpha=0,05)$.

\section{HASIL PENELITIAN}

\section{Analisis Univariat}

Hasil penelitian diperoleh responden sebanyak 55 orang dengan karakteristik responden berdasarkan hasil penelitian persentase tertinggi berada pada kelompok umur 20-35 tahun sebanyak 33 orang (60 $\%$ ), tingkat pendidikan responden mayoritas di kelompok pendidikan tingkat SMU sebanyak 31 orang $(56,36 \%)$, PT sebanyak 21 orang $(38,2 \%)$ dan SMP sebanyak 22 orang $(5,5 \%)$. Responden paling banyak adalah tidak mendukung sebanyak 31 orang $(56,4 \%)$, mendukung sebanyak 24 orang $(43,6 \%)$.Distribusi responden paling banyak adalah tidak trauma sebanyak 41 orang $(74,5 \%)$, mendukung sebanyak 14 orang $(25,5 \%)$. responden mayoritas dengan pengetahuan cukup sebanyak 27 orang $(49,1 \%)$,diikuti pengetahuan kurang sebanyak 18 orang $(32,7 \%)$ dan pengetahuan baik sebanyak 10 orang $(18,2 \%)$. responden dengan tingkat kecemasan responden paling banyak adalah kategori sedang sebanyak 38 orang $(69,1 \%)$ diikuti cemas ringan sebanyak 14 orang $(25,5 \%)$ dan berat sebanyak 3 orang $(5,5 \%)$.

\section{Analisis Bivariat}

Analisis bivariat dilakukan dengan menggunakan uji Chi-square pada tingkat kemaknaan 95\% $(0,05)$. Jika hasil uji menunjukkan nilai $\mathrm{p} \leq 0,05$ artinya ada pengaruh yang bermakna atau signifikan.

1. Pengaruh umur terhadap Kecemasan ibu pre operasi Setcio Caesarea.

Tabel 1. Tabulasi Silang antara umur terhadap Kecemasan ibu pre operasi Setcio Caesarea.

\begin{tabular}{|c|c|c|c|c|c|c|c|c|c|c|}
\hline \multirow{2}{*}{$\begin{array}{l}\mathbf{N} \\
\mathbf{0}\end{array}$} & \multirow{2}{*}{$\begin{array}{c}\text { Um } \\
\text { ur }\end{array}$} & \multicolumn{2}{|c|}{ Ringan } & \multicolumn{2}{|c|}{ Sedang } & \multicolumn{2}{|c|}{ Berat } & \multicolumn{2}{|c|}{ Total } & \\
\hline & & $\mathbf{n}$ & $\%$ & $\mathbf{n}$ & $\%$ & n & $\%$ & $\mathbf{n}$ & $\%$ & \\
\hline 1 & $\begin{array}{l}20- \\
35\end{array}$ & 13 & $\begin{array}{c}23 \\
6 \\
3\end{array}$ & $\begin{array}{l}2 \\
0\end{array}$ & $\begin{array}{l}36, \\
36\end{array}$ & 0 & $\begin{array}{c}0, \\
00\end{array}$ & $\begin{array}{l}3 \\
3\end{array}$ & $\begin{array}{l}6 \\
0\end{array}$ & $\begin{array}{l}\mathbf{0 , 0} \\
\mathbf{0 3}\end{array}$ \\
\hline 2 & $\begin{array}{l}> \\
35\end{array}$ & 1 & $\begin{array}{l}1, \\
81\end{array}$ & $\begin{array}{l}1 \\
8\end{array}$ & $\begin{array}{l}32, \\
72\end{array}$ & 3 & $\begin{array}{l}5, \\
45\end{array}$ & $\begin{array}{l}2 \\
2\end{array}$ & $\begin{array}{l}4 \\
0\end{array}$ & \\
\hline
\end{tabular}

Berdasarkan tabel diatas diketahui bahwa responden paling banyak usia 20-35 tahun mengalami kecemasan sedang sebanyak 20 orang (36,36 \%). Hasil uji statistic dengan menggunakan Chi Square menunjukkan $\mathrm{p}=0,003(\mathrm{p}>0,05)$ ada pengaruh antara umur dengan Kecemasan ibu pre operasi Setcio Caesarea.

\section{Pengaruh Pendidikan terhadap Kecemasan ibu pre operasi Setcio Caesarea.}

\section{Tabel 2.Tabulasi Silang antara Pendidikan terhadap Kecemasan ibu pre Operasi}

\begin{tabular}{|c|c|c|c|c|c|c|c|c|c|}
\hline \multirow{3}{*}{$\begin{array}{l}\mathbf{N} \\
\mathbf{0}\end{array}$} & \multirow{3}{*}{$\begin{array}{c}\text { Pend } \\
\text { idika } \\
\quad \mathbf{n}\end{array}$} & \multicolumn{8}{|c|}{ Kecemasan } \\
\hline & & \multicolumn{2}{|c|}{$\begin{array}{c}\text { Ringa } \\
\mathbf{n}\end{array}$} & \multicolumn{2}{|c|}{$\begin{array}{c}\text { Seda } \\
\text { ng }\end{array}$} & \multicolumn{2}{|c|}{$\begin{array}{c}\text { Bera } \\
\mathbf{t}\end{array}$} & \multicolumn{2}{|c|}{ Total } \\
\hline & & $\mathbf{n}$ & $\%$ & $\mathbf{N}$ & $\%$ & $\mathbf{n}$ & $\%$ & $\mathbf{n}$ & $\%$ \\
\hline 1 & SMP & 0 & $\begin{array}{c}0 . \\
00\end{array}$ & 0 & $\begin{array}{c}0, \\
00\end{array}$ & & $\begin{array}{l}5, \\
4 \\
5\end{array}$ & 3 & $\begin{array}{l}5, \\
45\end{array}$ \\
\hline
\end{tabular}

\begin{tabular}{cccccccccc}
\hline & SMA & 1 & 1, & 3 & 54 & 0 & 0, & 3 & 56 \\
& & 82 & 0 &, 5 & & 0 & 1 &, 3 \\
& & & & & 4 & & 0 & & 6 \\
& & & & & & & & & \\
2 & PT & 1 & 23 & 8 & 14 & 0 & 0, & 2 & 38 \\
& & 3 &, 6 & &, 5 & & 0 & 1 &, 1 \\
& & & 5 & & 4 & & 0 & & 9
\end{tabular}

Berdasarkan tabel diatas diketahui bahwa responden paling banyak pendidikan SMA mengalami kecemasan sedang sebanyak 31 orang ( 56,36 $\%)$.Hasil uji statistic dengan menggunakan $\mathrm{Chi}$ Square menunjukkan $\mathrm{p}=0,000(\mathrm{p}<0,05)$ ada pengaruh antara pendidikan dengan kecemasan ibu pre operasi.

3. Pengaruh Paritas terhadap Kecemasan ibu pre operasi Setcio Caesarea.

\section{Kecemasan}


Tabel 3. Tabulasi Silang antara

Paritas

terhadap Kecemasan ibu pre

Operasi

\begin{tabular}{|c|c|c|c|c|c|c|c|c|c|c|}
\hline \multirow{3}{*}{$\begin{array}{l}\mathbf{N} \\
\mathbf{0}\end{array}$} & \multirow{3}{*}{$\begin{array}{r}\text { Tra } \\
\text { uma }\end{array}$} & \multicolumn{8}{|c|}{ Kecemasan } & \multirow{3}{*}{$\mathbf{P}$} \\
\hline & & \multicolumn{2}{|c|}{$\begin{array}{c}\text { Ring } \\
\text { an }\end{array}$} & \multicolumn{2}{|c|}{$\begin{array}{c}\text { Sedan } \\
\mathrm{g}\end{array}$} & \multicolumn{2}{|c|}{$\begin{array}{c}\text { Bera } \\
\mathbf{t}\end{array}$} & \multicolumn{2}{|c|}{ Total } & \\
\hline & & $\mathbf{n}$ & $\%$ & $\mathbf{n}$ & $\%$ & n & $\%$ & $\mathbf{n}$ & $\%$ & \\
\hline 1 & $\begin{array}{l}\text { Prim } \\
\text { ipar } \\
\text { a }\end{array}$ & 6 & $\begin{array}{c}10 \\
9 \\
0\end{array}$ & 1 & $\begin{array}{l}1, \\
81\end{array}$ & 0 & $\begin{array}{l}0, \\
0 \\
0\end{array}$ & 7 & $\begin{array}{c}12 \\
7 \\
2\end{array}$ & $\begin{array}{l}\mathbf{0} \\
00 \\
2\end{array}$ \\
\hline 2 & $\begin{array}{l}\text { Mult } \\
\text { i } \\
\text { Para }\end{array}$ & 6 & $\begin{array}{c}10 \\
9 \\
0\end{array}$ & $\begin{array}{l}2 \\
4\end{array}$ & $\begin{array}{c}43 \\
, 6 \\
3\end{array}$ & 1 & $\begin{array}{l}1, \\
8 \\
1\end{array}$ & $\begin{array}{l}3 \\
1\end{array}$ & $\begin{array}{c}56 \\
, 3 \\
7\end{array}$ & \\
\hline 3 & $\begin{array}{l}\text { Gra } \\
\text { nde } \\
\text { Mult } \\
\text { ipar } \\
\text { a }\end{array}$ & 2 & $\begin{array}{l}3, \\
63\end{array}$ & $\begin{array}{l}1 \\
3\end{array}$ & $\begin{array}{c}23 \\
, 6 \\
3\end{array}$ & 2 & $\begin{array}{l}3 \\
6 \\
3\end{array}$ & $\begin{array}{l}1 \\
7\end{array}$ & $\begin{array}{c}30 \\
9 \\
1\end{array}$ & \\
\hline
\end{tabular}

Berdasarkan tabel diatas diketahui bahwa responden paritas paling banyak multi para mengalami cemas sedang sebanyak 24 orang $(43,63 \%)$ berat 1 orang $(1,81 \%)$ dan mayoritas cemas berat berada pada paritas grande multipara sebanyak 2 orang $(3,63 \%)$. Hasil uji statistic dengan menggunakan Chi Square menunjukkan $\mathrm{p}=0,002(\mathrm{p}<0,05)$ ada pengaruh antara Paritas dengan Kecemasan ibu pre operasi.

4. Pengaruh Dukungan terhadap Kecemasan ibu pre operasi Setcio Caesarea.

Tabel 4. Tabulasi Silang antara Dukungan terhadap Kecemasan ibu pre Operasi

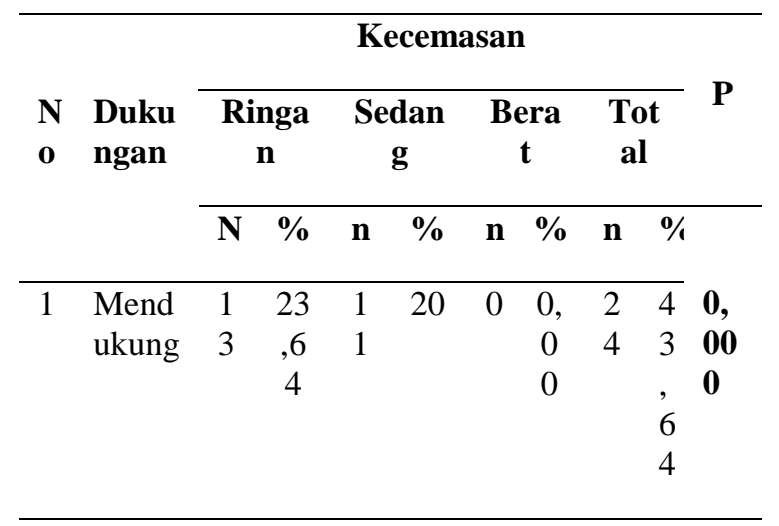

\begin{tabular}{lllllllll}
\hline 2 Tidak & 1 & 1, & 2 & 49 & 3 & 5, & 3 & 5 \\
mend & & 82 & 7 &, 1 & & 4 & 1 & 6 \\
ukun & & & & 0 & & 5 & &, \\
g & & & & & & & & 3 \\
& & & & & & & & 6
\end{tabular}

Berdasarkan tabel diatas diketahui bahwa responden dengan tidak mendukung mengalami kecemasan sedang sebanyak 27 orang (49,10\%), cemas ringan dengan adanya dukungan sebanyak 13 orang $(23,64 \%)$ dan mengalami kecemasan berat oleh karena tidak adanya dukungan sebanyak 3 orang $(5,45 \%)$. Hasil uji statistic dengan menggunakan Chi Square menunjukkan $\mathrm{p}=0,000(\mathrm{p}<0,05)$ ada pengaruh antara Dukungan dengan Kecemasan ibu pre operasi.

5. Pengaruh Trauma terhadap Kecemasan ibu pre operasi Setcio Caesarea.

Tabel 5. Tabulasi Silang antara Trauma terhadap Kecemasan ibu pre Operasi

\begin{tabular}{|c|c|c|c|c|c|c|c|c|c|c|}
\hline \multirow{3}{*}{$\begin{array}{l}\mathbf{N} \\
\mathbf{0}\end{array}$} & \multirow{3}{*}{$\begin{array}{l}\text { Tra } \\
\text { um } \\
\mathbf{a}\end{array}$} & \multicolumn{8}{|c|}{ Kecemasan } & \multirow{3}{*}{$\mathbf{P}$} \\
\hline & & \multicolumn{2}{|c|}{$\underset{\mathbf{n}}{\text { Ringa }}$} & \multicolumn{2}{|c|}{$\begin{array}{c}\text { Sedan } \\
\mathrm{g}\end{array}$} & \multicolumn{2}{|c|}{$\begin{array}{c}\text { Bera } \\
\mathbf{t}\end{array}$} & \multicolumn{2}{|c|}{ Total } & \\
\hline & & $\mathbf{n}$ & $\%$ & $\mathbf{n}$ & $\%$ & $\mathbf{n}$ & $\%$ & $\mathbf{n}$ & $\%$ & \\
\hline 1 & Ada & 0 & $\begin{array}{c}0, \\
00\end{array}$ & $\begin{array}{l}1 \\
1\end{array}$ & $\begin{array}{c}20 \\
, 0 \\
0\end{array}$ & 3 & $\begin{array}{l}5, \\
4 \\
5\end{array}$ & $\begin{array}{l}1 \\
4\end{array}$ & $\begin{array}{l}25 \\
4 \\
5\end{array}$ & $\begin{array}{l}\mathbf{0}, \\
\mathbf{0 0} \\
\mathbf{1}\end{array}$ \\
\hline 2 & $\begin{array}{l}\text { Tid } \\
\text { ak } \\
\text { ada }\end{array}$ & $\begin{array}{l}1 \\
4\end{array}$ & $\begin{array}{c}25 \\
, 4 \\
5\end{array}$ & $\begin{array}{l}2 \\
7\end{array}$ & $\begin{array}{c}49 \\
, 0 \\
9\end{array}$ & 0 & $\begin{array}{l}0 \\
0 \\
0\end{array}$ & $\begin{array}{l}4 \\
1\end{array}$ & $\begin{array}{c}74 \\
5 \\
5\end{array}$ & \\
\hline
\end{tabular}

Berdasarkan tabel diatas diketahui bahwa responden dengan ada trauma mengalami kecemasan sedang sebanyak 11 orang $(20,00 \%)$ berat sebanyak 3 orang $(5,45 \%)$.Hasil uji statistic dengan menggunakan Chi Square menunjukkan $\mathrm{p}=0,001(\mathrm{p}<0,05)$ ada pengaruh antara trauma dengan Kecemasan ibu pre operasi.

6. Pengaruh Pengetahuan terhadap Kecemasan ibu pre operasi Setcio Caesarea.

Tabel 6. Tabulasi Silang antara Pengetahuan terhadap Kecemasan ibu pre Operasi 


\begin{tabular}{|c|c|c|c|c|c|c|c|c|c|}
\hline \multirow{2}{*}{$\begin{array}{l}\mathbf{N} \\
\mathbf{0}\end{array}$} & \multirow{2}{*}{$\begin{array}{c}\text { Peng } \\
\text { etahu } \\
\text { an }\end{array}$} & \multicolumn{2}{|c|}{$\begin{array}{c}\text { Ring } \\
\text { an }\end{array}$} & \multicolumn{2}{|c|}{$\begin{array}{c}\text { Seda } \\
\text { ng }\end{array}$} & \multicolumn{2}{|c|}{$\begin{array}{c}\text { Bera } \\
\mathbf{t}\end{array}$} & \multicolumn{2}{|c|}{ Total } \\
\hline & & $\mathbf{n}$ & $\%$ & $\mathbf{n}$ & $\%$ & $\mathbf{n}$ & $\%$ & $\mathbf{n}$ & $\%$ \\
\hline 1 & Baik & 8 & $\begin{array}{r}14 \\
5 \\
4\end{array}$ & 2 & $\begin{array}{l}3, \\
63\end{array}$ & 0 & $\begin{array}{l}0, \\
0 \\
0\end{array}$ & $\begin{array}{l}1 \\
0\end{array}$ & $\begin{array}{c}18 \\
, 1 \\
8\end{array}$ \\
\hline
\end{tabular}

\begin{tabular}{llcccccccc}
\hline 2 & Cuku & 6 & 10 & 2 & 38 & 0 & 0, & 2 & 49 \\
& $\mathrm{p}$ & &, 9 & 1 &, 1 & & 0 & 7 &, 1 \\
& & & 1 & & 8 & & 0 & & 0 \\
& & & & & & & & & \\
2 & Kuran & 0 & 0, & 1 & 27 & 3 & 5, & 1 & 32 \\
& g & & 00 & 5 &, 2 & & 4 & 8 &, 7 \\
& & & & & 7 & & 5 & & 2
\end{tabular}

Berdasarkan tabel diatas diketahui bahwa responden dengan pengetahuan baik megalami kecemasan ringan sebanyak 8 orang ( $14,54 \%)$, pengetahuan cukup paling banyak mengalami kecemasan sedang sebanyak 21 orang $(38,18 \%)$ dan pengetahuan kurang mengalami kecemasan sedang sebanyak 15 orang $(27,27 \%)$. Hasil uji statistic dengan menggunakan Chi Square menunjukkan $\mathrm{p}=0,000(\mathrm{p}<0,05)$ ada pengaruh antara pengetahuan dengan kecemasan ibu pre operasi.

\section{PEMBAHASAN}

Pengaruh Usia terhadap kecemasan ibu Pre Operasi Sectio Caesarea

Berdasarkan hasil penelitian diketahui bahwa responden paling banyak usia 20-35 tahun mengalami kecemasan sedang sebanyak 20 orang ( $36,36 \%$ ). Hasil uji statistic dengan menggunakan Chi Square menunjukkan $\mathrm{p}=0,003(\mathrm{p}>0,05)$ ada pengaruh antara umur dengan Kecemasan ibu pre operasi Setcio Caesarea. Kecemasan merupakan perasaan yang paling umum yang dirasakan seseorang, dimana kecemasan menunjukkan reaksi terhadap bahaya yang memperingatkan orang dari dalam secara naluri bahwa adanya bahaya dan orang bersangkutan mungkin kehilangan kendali dalam situasi tersebut, Manuaba (2006) juga menyebutkan bahwa usia dapat memengaruhi kecemasan pada ibu yang akan bersalin bahwa usia $<20$ tahun dan $>30$ tahun akan memberi dampak terhadap perasaan cemas semakin muda usia atau semakin tua akan beresiko terhadap proses persalinan. Kedewasaan merupakan masalah penting dalam perkembangan kepribadian, membangun kekuatan yang besar untuk menggerakkan tingkah laku dalam berfikir.

\section{Pengaruh Pendidikan terhadap kecemasan ibu Pre Operasi Sectio Caesarea}

Berdasarkan tabel diatas diketahui bahwa responden paling banyak pendidikan SMA mengalami kecemasan sedang sebanyak 31 orang ( 56,36 \%), pendidikan SMP dengan kecemasan berat sebanyak 3 orang $(5,45 \%)$. Hasil uji statistic dengan menggunakan Chi Square menunjukkan $\mathrm{p}=0,000 \quad(\mathrm{p}<0,05)$ ada pengaruh antara pendidikan dengan kecemasan ibu pre operasi. Pada penelitian ini jelas perbedaan kecemasan dari pendidikan rendah mengalami kecemasan berat dan sedang, pendidikan membentuk akan suatu ketahuan responden terhadap tindakan, namun demikian ada juga responden dengan pendidikan tinggi mengalami kecemasan sedang sebanyak 8 orang $(14,54 \%)$ menurut asumsi peneliti hal ini bisa saja disebabkan meskipun pendidikan nya tinggi tetap saja ada kekawatiran yang mencemaskan pada responden diebabkan oleh pikiran pikiran negatif dari tindakan tersebut.

\section{Pengaruh Paritas terhadap kecemasan ibu Pre Operasi Sectio Caesarea}

Hasil penelitian ini menujukkan bahwa responden paritas paling banyak multi para mengalami cemas sedang sebanyak 24 orang $(43,63 \%)$ berat 1 orang $(1,81 \%)$ dan mayoritas cemas berat berada pada paritas grande multipara sebanyak 2 orang (3,63\%). Hasil uji statistic dengan menggunakan Chi Square menunjukkan $\mathrm{p}=0,002(\mathrm{p}<0,05)$ ada pengaruh antara paritas dengan kecemasan ibu pre operasi. Manuaba (2006) menjelaskan bahwa ibu yang akan bersalin akan merasakan kecemasan terkait dengan aspek psikologis dimana belum ada gambaran pengalaman bagi ibu yang pertama kali mengalami proses persalinan atau dengan tindakan operasi , atau disebabkan karena adanya ketakutan oleh karena mendengarkan pengalaman dari orang lain misalnya meninggal atau megalami efek komplikasi saat melahirkan. Responden dengan paritas grande multi para mengalami kecemasan berat dapat disebabkan oleh karena pikiran akan anaknya yang banyak akan menjadi beban pikiran akan bagaimana keadaan anak anaknya apabila terjadi sesuatu ketika menjalani tindakan operasi.

\section{Pengaruh Dukungan terhadap kecemasan ibu Pre Operasi Sectio Caesarea}

Hasil penelitian menunjukkan bahwa responden dengan tidak mendukung mengalami kecemasan sedang sebanyak 27 orang (49,10\%), cemas ringan dengan adanya dukungan sebanyak 13 orang $(23,64 \%)$ dan mengalami kecemasan berat oleh karena tidak adanya dukungan sebanyak 3 orang $(5,45 \%)$. Hasil uji statistic dengan menggunakan Chi Square menunjukkan $\mathrm{p}=0,000(\mathrm{p}<0,05)$ ada pengaruh antara Dukungan dengan Kecemasan ibu pre operasi. Dukungan yang baik akan memberikan kekutan pada ibu, memberikan rasa percaya diri, perasaan nyaman ,diperhatikan akan kebutuhan secara psikologis untuk menjalani tindakan. Persalinan dengan sectio caesarea merupakan masa yang cukup berat bagi ibu, dimana proses persalinan dan melahirkan adalah sesuatu layaknya bertaruh nyawa antara hidup dan mati baik 
yang belum pernah maupun yang sudah berpengalaman, dukungan pendampingan suami dan orang terdekat merupakan sumber kekuatan bagi ibu yang tidak dapat diberikan oleh tenaga kesehatan dimana merupakan sebuah energi bagi ibu bahwa dia merasakan adanya perhatian,penghargaan sehingga akan memotivasi dan memberikan ketenangan bagi ibu.

\section{Pengaruh Trauma terhadap kecemasan ibu Pre Operasi Sectio Caesarea}

Dari hasil penelitian diketahui bahwa responden mengalami trauma adalah responden previus yang sudah pernah berpengalaman menjalani proses persalinan dengan sectio caesarea kecemasan karena berada diruang operasi dengan tidak didampingi keluarga, ketakutan akan bagaimana bekas operasi sebelumnnya disayat kembali,kuatir dengan efek operasi yang pernah dialami oleh responden dengan ada trauma mengalami kecemasan sedang sebanyak 11 orang ( $20,00 \%)$ berat sebanyak 3 orang $(5,45 \%)$. Hasil uji statistic dengan menggunakan Chi Square menunjukkan $\mathrm{p}=0,001(\mathrm{p}<0,05)$ ada pengaruh antara trauma dengan Kecemasan ibu pre operasi. Segala bentuk prosedur pembedahan selalu didahului dengan suatu reaksi emosional tertentu oleh pasien, apakah reaksi tersebut jelas atu tersembunyi, normal, atau abnormal. Sebagai contoh ansietas praoperatif kemungkinan merupakan suatu respon antisipasi terhadap suatu pengalaman yang dapat dianggap pasien sebagai suatu ancaman terhadap perannya dalam hidup, integritas tubuh, atau bahkan kehidupannya sendiri. Sudah diketahui bahwa pikiran yang bermasalah secara langsung mempengaruhi fungsi tubuh. Karenananya, penting artinya untuk mengidentifikasi ansietas yang dialami pasien (Smeltzer,2001).

\section{Pengaruh Pengetahuan terhadap kecemasan ibu Pre Operasi Sectio Caesarea}

Pengetahuan erat hubungannya pada ibu yang akan menjalani sectio caesarea dengan bagaimana tingkat kecemasan pada ibu tersebut Berdasarkan tabel diatas diketahui bahwa responden dengan pengetahuan baik megalami kecemasan ringan sebanyak 8 orang ( $14,54 \%$ ), pengetahuan cukup paling banyak mengalami kecemasan sedang sebanyak 21 orang $(38,18 \%)$ dan pengetahuan kurang mengalami kecemasan sedang sebanyak 15 orang $(27,27 \%)$. Hasil uji statistic dengan menggunakan Chi Square menunjukkan $\mathrm{p}=0,000(\mathrm{p}<0,05)$ ada pengaruh antara pengetahuan dengan Kecemasan ibu pre operasi. Menurut Notoadmojo (2010) bahwa pengetahuan merupakan domain yang sangat penting untuk membentuk suatu tindakan .Pengetahuan dapat membentuk perilaku sehingga ada keyakinan seseorang dari ketahuannya sehingga membentuk suatu perilaku akan disesuaikan dengan pengetahuaannya seseorang menghadapi stressor.

\section{PENUTUP \\ Kesimpulan}

1. Berdasarkan hasil penelitian, dapat disimpulkan bahwa Umur ( $p$-value $=0,003)$, Pendidikan $(p$-value $=0,000)$, Paritas $(p$-value $=$ $0,002)$, Trauma ( $p$-value $=0,001)$, Dukungan $(p$ value $=0,000)$ pengetahuan $(p$-value $=0,000)$ memengaruhi kecemasan ibu pre operasi sectio caesarea.

2. Bedah caesarea adalah suatu usaha untuk menyelamatkan ibu dan janin meskipun sudah bergeser dengan alasan alasan tertentu sehingga ibu memilih tindakan operasi namun setelah diteliti mayoritas ibu tetap merasakan adanya kecemasan akan tindakan tersebut.

\section{Saran}

1. Kepada keluarga dan orang terdekat pasien agar senantiasa memberikan dukungan untuk meyakinkan ibu bahwa orang terdekatnya memberikan support melalui komunikasi, sentuhan kasih sayang serta doa kepada Tuhan Yang Maha Esa untuk kesiapannya menghadapi tindakan operasi sectio Caesarea.

2. Kepada tenaga Kesehatan

Agar memberikan dukungan melalui komunikasi terapeutik sehingga ketika memberikan penjelasan tentang prosedur tindakan operasi akan memberikan pemahaman dan mengelola psikologis yang baik untuk menghadapi operasi sectio Caesarea sehingga kecemasan ibu pre operasi dapat diatasi.

\section{DAFTAR PUSTAKA}

1. Alimul, Aziz. Riset Keperawatan dan Teknik Penulisan Ilmiah. Jakarta: Salemba Medika;2003

2. Aprilia. Faktor-faktor yang Mempengaruhi Tingkat Kecemasan Pasien yang Akan Menghadapi Operasi di RSUD Sumedang:

[Tesis]. Sumedang : Universitas Islam Negeri;2013

3. Dwi Hastuti. Huungan pengetahuan tentang Sectio Caesarea Dengan Kecemasan ibu Pre Operasi di Ruang Catleya Rumah Sakit Panti Waluyo Surakarta;2015.

4. Bobak, Lowdermilk \& Jansen, Buku Ajar Keperawatan Maternitas, Edisi 6, EGC,Jakarta.

5. Brunner \& Sudart, Buku Ajar Keperawsatan medikal Bedah, Edisi 8 Volume 1, EGC,Jakarta;2001

6. Etik Kristiyani. Hubungan Status Paritas dengan Tingkat Kecemasan ibu Pre Operasi 
Sectio Caesarea di PKU Muhammadiyah Sukoharjo;2015.

7. Hamilton,D,M,Dasar-dasar Keperawatan Maternitaas, Edisi 6,EGC,Jakarta,1995.

8. Gunarsa D Singgih, Yulia, Psikologi Perawatan, BPK Gunung Mulia; 2012.

9. Hastuti, D. (2015). Hubungan Pengetahuan Tentang Sectio Caesarea dengan Kecemasan Ibu Pre Operasi Di Ruang Catleya Rumah Sakit Panti Waluyo Surakarta.Skripsi S-1 keperawatan. Stikes Kusuma Husada. Surakarta.

https://d1wqtxts1xzle7.cloudfront.net/53367131/0 1-gdl-dwihastuti-1075-1-1_fullt-i_1.pdf

10. Janiwarty, B dan Pieter, H. Z. Pendidikan Psikologi untuk Bidan Suatu Teori dan Terapannya, Yogyakarta: Rapha Publishing 11. Kemenkes RI. Riset Kesehatan Dasar. Jakarta. Badan Penelitian dan Pengembangan Kesehatan Kementrian Kesehatan RI; 2018.

12. Kasdu, D. Operasi Caesar Masalah dan Solusinya. Jakarta: Puspa Swara

13. Lely Herlina,M Ari Fardiansyah Hubungan Dukungan Keluarga Dengan Tingkat Kecemasan Pasien Pre Operasi Sectio Caesarea Di Rumah sakit Umum Daerah Al-Iksan Bandung;2012 14. Notoatmodjo S. Metodologi penelitian. Cetakan I ed. Jakarta: Rineka Cipta; 2010.

15. Oxorn, Harry dan William R. Forte. Ilmu Kebidanan, Patologi dan Fisiologi Persalinan. Yogyakarta: Yayasan Esentia Medika (YEM); 2010.

16. Potter dan Perry Buku Ajar Fundamental Keperawatan: Konsep, Proses dan Praktik (ed. 4 Vol. 2). Jakarta: EGC

17. Sriningsing Iis,Dani A, Tingkat Kecemasan Pasien Preoperatif pada Pembedahan Seksio Sesarea di Ruang Srikandi RSUD Kota Semarang. [dokumen di internet].2016 http://stikeskusumahusada.ac.id/digilib/files/disk1 /22/01-gdl-dwihastuti-1075-1-1_fullt-i.pdf 